\title{
吸い出しと空洞形成及び陥没過程の可視化と 防止対策としてのフィルター層の有効性
}

\author{
小林 孝彰 1 ・佐々 真志 2 ・梁 順普 3 後藤 翔矢 4 \\ 1 正会員 国立研究開発法人 海上・港湾・航空技術研究所 港湾空港技術研究所 \\ （干239-0826 神奈川県横須賀市長瀬 3-1-1） \\ E-mail: kobayashi-t@pari.go.jp \\ 2 正会員 国立研究開発法人 海上・港湾・航空技術研究所 港湾空港技術研究所 (同上) \\ E-mail: sassa@pari.go.jp \\ 3 国立研究開発法人＼cjkstart海上・港湾・航空技術研究所 港湾空港技術研究所（同上） \\ E-mail: yan-s2@pari.go.jp \\ 4 国立研究開発法人 海上・港湾・航空技術研究所 港湾空港技術研究所（同上） \\ E-mail: gotou-s843g@pari.go.jp
}

\begin{abstract}
護岸・岸壁などの港湾施設における吸い出し防止策として，裏込石と裏埋砂の間に二層の粒度調整砕石 からなるフィルター層を設ける方法に着目し，その実用性を総合的に検討した。その結果，単粒度のフィ ルター層を対象とした目詰まり効果の検証により, 国際基準に定められる従来のフィルター材と比較して, 同等かそれ以上の効果を持つことを示した. また地震荷重, 交通荷重を想定した繰り返し載荷試験からは, 二層の粒度調整砕石から成るフィルター層が十分な力学的安定性を有することが明らかとなった．裏埋砂 を用いた模型実験により，実現象に近いスケールで吸い出し，空洞形成，地表面陷没の一連の過程を可視 化すると共に，裏埋砂の粒径に起因するサクションの大きさが，これらのプロセスに多大な影響を及ぼす ことを示し，フィルター層の吸い出し防止効果を実証した.
\end{abstract}

Key Words : erosion, cavity formation, subsidence, geotechnical filter, discrete element method

\section{1. 序論}

護岸・岸壁などの港湾施設において，裏埋砂の吸い出 しによって発生する地盤内の空洞形成，地表面の陷没が 問題となっている．筆者らはこれまでに，吸い出し防止 対策として裏込石と裏埋砂の間に粒度調整砕石から成る フィルター層を設ける方法1)に着目した検討を行った

(図-1).フィルター層の存在により, 防砂シートの損傷 を抑制するだけでなく，損傷が起こった場合にも裏埋砂 の目詰まりによって吸い出しを抑止する効果が期待でき る. このようなフィルター層については，ダム，グラベ ルドレーン2)などの分野で古くから研究がなされている。 しかしながら当検討で対象とするフィルター層は，裏埋 砂の吸い出しを抑止しつつ，直下の裏込石に対して安定 的に敷設可能でなくてはならないという点において特殊 である．上記の条件を満たすために，筆者らは実験的事 実に基づいて二層構造のフィルター層を提案した ${ }^{1}$ （図 -1). 本検討では, このような二層構造のフィルター層の
実用性を実証すべく，以下の総合的な検討を行った。

はじめに，裏埋砂に対するフィルター層の目詰まり効 果を実験によって評価し，既往の国際基準3)と比較した。 次に、二層構造のフィルター層内部の力学的安定性の検 証を目的として, 地震及び交通荷重を想定した繰り返し 載荷試験を行った. 最後に、模型実験によって吸い出し, 空洞形成，陥没の一連過程を観察するとともに，フィル タ一層による吸い出し抑止効果を検証した.

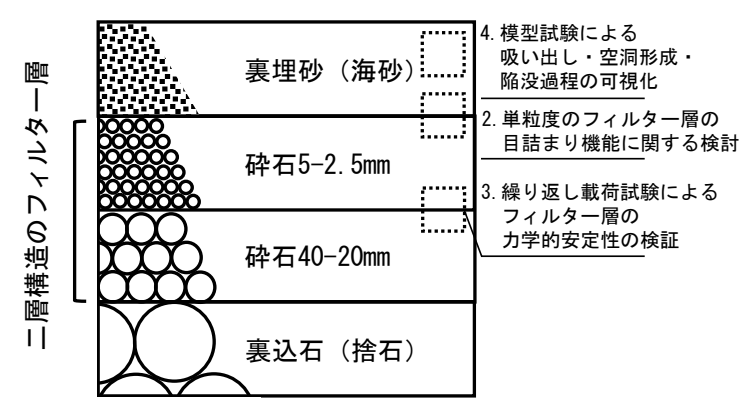

図-1 二層構造のフィルター層の概念図 


\section{2. 単粒度のフィルター材の目詰まり効果に 関する検討}

地盤材料のフィルター概念については古くから研究 がなされており，例えば表-1 に示寸国際基準 3)が存在す る。しかしながらこれらの基準は，フィルタ一層の材料 にある程度の粒度分布（均等係数 $U_{c}=3$ 以上）を前提と している. 対して本検討では，序論で述べる通り二層構 造のフィルター層を採用したことから，裏埋砂と接する 第一層目のフィルターに均等係数の低い材料 $\left(U_{c}=\right.$ 1.35-1.85）を採用することとなり，既往の知見とは条件 が異なる．そこで，単粒度のフィルター材の目詰まり機 能を改めて評価するため，簡易振動台を用いた実験を行 い，国際基淮との比較を行った，なお試験の方法は，文 献1) と同様である.

はじめに, 図-2 に示すアクリル円筒形容器 (内径 $15 \mathrm{~cm}$, 高さ $30 \mathrm{~cm}$ ）にフィルター層として粒度調整砕石を厚さ $13 \mathrm{~cm}$ に敷設し，その上に裏埋砂を $2,500 \mathrm{~g}$ 投入した。 そ の後, 容器に振動（1.5 G，3 Hz，10 分間）を与え, フィ ルター層を通過して受け典に溜まった裏埋砂の量を計測 した. 裏埋砂としては, 後述する吸い出しの模型実験に 用いた海砂 $\mathrm{B}\left(D_{50}=0.585 \mathrm{~mm}\right)$ に加え, 珪砂 4 号 $\left(D_{50}=\right.$ $0.584 \mathrm{~mm})$, 及び珪砂 5 号 $\left(D_{50}=0.341 \mathrm{~mm}\right)$ を用いた. フィ ルター層には, 3 種類の粒度調整砕石 (13-5 mm, 20-5 mm, 40-20 mm)を用いた。これらの粒度分布を図-3に示す.

試験ケースと結果の一覧を表-2 に示寸. また図-4には, 試験結果をフィルター材と裏埋砂の中央粒径比 $\left(D_{F 50}\right.$ $/ D_{\text {S50 }}$ )で整理したものを示寸．国際基準には 15 \%粒径比 $\left(D_{F 15} / D_{S 15}\right)$ を用いるものがあるが，本検討のフィルター 材が単粒度であることから，中央粒径比での整理が適当 であると考えられる．なお，裏埋砂のフィルター材通過 率が 30 \%以上であった試験結果は, グラフ上方にまとめ て示している. 試験結果より，中央粒径比がおおよそ 20 以下であればフィルター材が目詰まり効果を発揮し, 吸 い出しが抑止されることが分かる．対して国際基準 3)で は，均一なフィルターに対して中央粒径比が 5 以下（粗 (砂)，あるいは10以下（細かい砂）と定めている。試 験結果より，本検討で用いた単粒度のフィルター材は, 従来のフィルター材と同等か，あるいはそれ以上の目詰 まり効果を発揮することものと考えられる.

表-1 フィルター概念に関する主な国際基準

\begin{tabular}{|l|l|l|}
\hline \multicolumn{1}{|c|}{ 国際基準 } & \multicolumn{1}{|c|}{ 内容 } & \multicolumn{1}{c|}{ 適用範囲 } \\
\hline \hline \multirow{5}{*}{$\begin{array}{l}\text { U.S. Bureau of } \\
\text { Reclamation } \\
\text { (1998) }\end{array}$} & $D_{F 50} / D_{S 50} \leq 5$ (粗い砂) & 均一なフィルター \\
& $D_{F 50} / D_{S 50} \leq 10$ (細かい砂) & $U_{c}=3-4$ \\
\cline { 2 - 3 } & $9 \leq D_{F 50} / D_{S 50} \leq 30$ & 粒度の広いフィルター \\
& $6 \leq D_{F 15} / D_{S 15} \leq 18$ & $U_{c}>4$, 角張った粒子 \\
\cline { 2 - 3 } & $12 \leq D_{F 50} / D_{S 50} \leq 58$ & 粒度の広いフィルター \\
& $12 \leq D_{F 15} / D_{S 15} \leq 40$ & $U_{c}>4$, や丸い粒子 \\
\hline
\end{tabular}

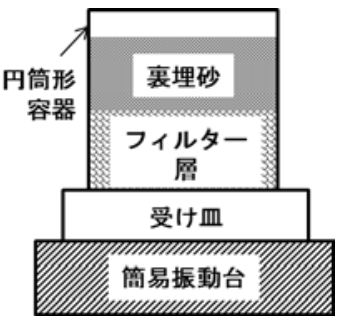

試験条件

・フィルター層厚 $13 \mathrm{~cm}$

·裏埋砂 $2,500 \mathrm{~g}$

$\cdot 1.5 \mathrm{G}, 3 \mathrm{~Hz}$ の振動を 10 分間

・フィルター層を通過した裏埋砂

の量を評価

図-2 フィルター層の目詰まり機能評価試験 1)

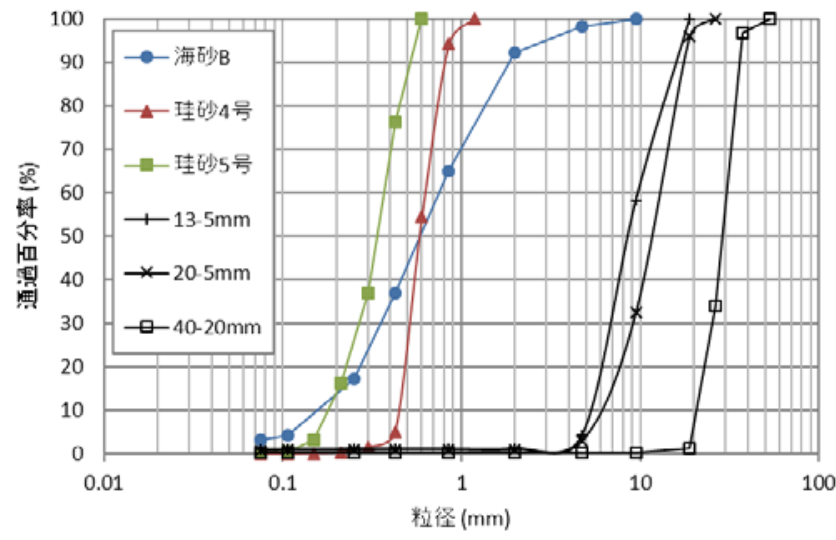

図-3 目詰まり試験に用いた材料の粒度分布

表-2 フィルター層の目詰まり試験の結果一覧

\begin{tabular}{|c|c|c|c|c|c|}
\hline $\begin{array}{l}\text { 試験 } \\
\text { ケース }\end{array}$ & $\begin{array}{c}\text { 上層 } \\
\text { 裏埋砂 }\end{array}$ & $\begin{array}{c}\text { 下層 } \\
\text { フィルター材 }\end{array}$ & $\begin{array}{c}\text { 中央粒径比 } \\
D_{F 50} / D_{S 50}\end{array}$ & $\begin{array}{c}\text { 通過量 } \\
\text { (g) }\end{array}$ & $\begin{array}{c}\text { 通過率 } \\
(\%)\end{array}$ \\
\hline 1 & \multirow{3}{*}{ 海砂B } & 砕石 13-5mm & 15.0 & 0.2 & $0.0 \%$ \\
\hline 2 & & 砕石 20-5mm & 21.0 & 0.2 & $0.0 \%$ \\
\hline 3 & & 砕石 40-20mm & 50.1 & 598.8 & $24.0 \%$ \\
\hline 4 & \multirow{3}{*}{ 硅砂4号 } & 砕石 13-5mm & 15.0 & 3.4 & $0.1 \%$ \\
\hline 5 & & 砕石 20-5mm & 21.1 & 49.8 & $2.0 \%$ \\
\hline 6 & & 砕石 40-20mm & 50.2 & 2422.6 & $96.9 \%$ \\
\hline 7 & \multirow{3}{*}{ 硅砂5号 } & 砕石 13-5mm & 25.7 & 2076.8 & $83.1 \%$ \\
\hline 8 & & 砕石 20-5mm & 36.1 & 2263.5 & $90.5 \%$ \\
\hline 9 & & 砕石 40-20mm & 86.0 & 2443.1 & $97.7 \%$ \\
\hline
\end{tabular}

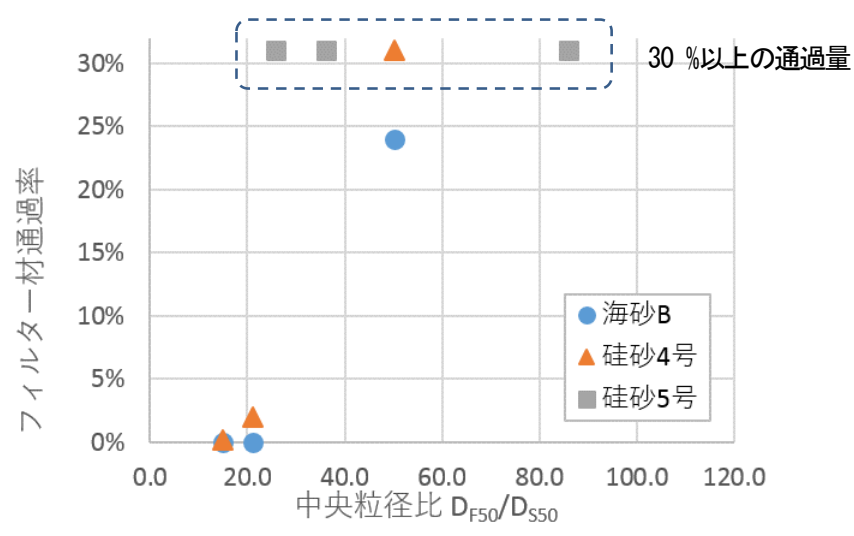

図-4 試験結果の中央粒径比による整理 


\section{3. 繰り返し載荷試験によるフィルター層の 力学的安定性の評価}

\section{(1) 試験概要}

二層構造のフィルター層の内部における力学的安定 性を検証するため，繰り返し載荷試験を行った．図-5に 示す大型単純せん断試験装置を用い，現場で想定される 地震荷重 (水平荷重), あるいは交通荷重（鉛直荷重）を 繰り返し与えて変形を測定した. 表-3に試験の対象とし たフィルター層の種類を示す．ケース 3，4，5 は二層構 造のフィルター層であり, ケース 1,5 は比較対象のため の単層構造である．また表-4には，フィルター層に用い た粒度調整砕石の物性を示す。

二層構造のフィルターの作成に際しては，上層試料が 下層試料へ入り込むために密度の管理が容易ではない. そこで，まず密度試験用の容器に $20 \mathrm{~cm}$ の高さから試料 を投入することを複数回繰り返し，再現性のある密度を 選んで供試体作製密度とした。こうして求めた密度は $1.510 \mathrm{~g} / \mathrm{cm}^{3}$ (5-2.5 mm), $1.540 \mathrm{~g} / \mathrm{cm}^{3}$ (20-2.5 mm), 1.548 $\mathrm{g} / \mathrm{cm}^{3}(20-5 \mathrm{~mm}), 1.568 \mathrm{~g} / \mathrm{cm}^{3}(40-20 \mathrm{~mm})$ であった. 供試体 作成後，上端面から $100 \mathrm{kPa}$ の鉛直拘束圧をかけて圧密

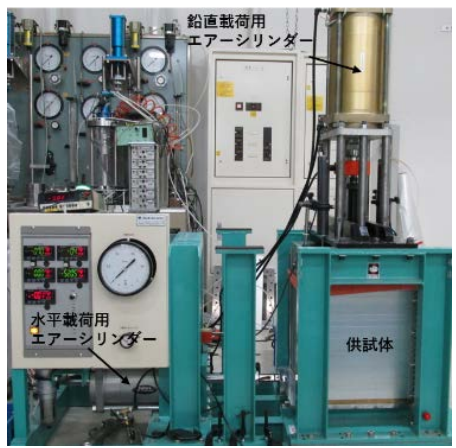

フィルター層供試体の寸法

図-5 載荷試験に用いた大型単純せん断試験装置

表-3 繰り返し載荷試験のケース一覧

\begin{tabular}{|c|c|c|}
\hline ケース & 下層試料 & 上層試料 \\
\hline \hline 1 & \multicolumn{2}{|c|}{$5-2.5 \mathrm{~mm}$} \\
\hline 2 & \multirow{2}{*}{$40-20 \mathrm{~mm} \quad 5-2.5 \mathrm{~mm}$} \\
\cline { 1 - 1 } \cline { 3 - 3 } & & $20-2.5 \mathrm{~mm}$ \\
\hline 4 & \multicolumn{2}{|c|}{$40-20 \mathrm{~mm}$} \\
\hline 5 & \multicolumn{2}{|c|}{} \\
\hline
\end{tabular}

表-4 フィルター層に用いた粒度調整砕石の物性

\begin{tabular}{|c|c|c|c|}
\hline $\begin{array}{c}\text { 粒度調整 } \\
\text { 砕石 }\end{array}$ & $\begin{array}{c}\text { 中央粒径 } \\
d_{50}(\mathrm{~mm})\end{array}$ & $\begin{array}{c}\text { 均等係数 } \\
U_{c}\end{array}$ & $\begin{array}{c}\text { 土粒子密度 } \\
\rho_{\mathrm{s}}\left(\mathrm{kg} / \mathrm{cm}^{3}\right)\end{array}$ \\
\hline \hline $5-2.5 \mathrm{~mm}$ & 2.81 & 3.93 & 2.716 \\
\hline $20-2.5 \mathrm{~mm}$ & 4.43 & 2.25 & 2.716 \\
\hline $20-5 \mathrm{~mm}$ & 11.3 & 1.85 & 2.715 \\
\hline $40-20 \mathrm{~mm}$ & 28.7 & 1.35 & 2.701 \\
\hline
\end{tabular}

し， $\pm 5 \% ， \pm 10 \% ， \pm 20 \% ， \pm 30 \%$ のん断応力比, あるいは鉛直応力比の正弦波振幅を与えた．載荷回数は 各応力段階で 50 回とし，最後の士30\%のみ 500 回とし た。

\section{(2) 試験結果}

地震荷重を想定した水平載荷試験について，各荷重段 階におけるフィルター層の沈下方向の軸ひずみを図-6 に示す．全てのケースにおいて，応力振幅の増加に伴い 軸ひずみが増加する結果となった．特に，せん断応力比 が 0.2 を超えると軸ひずみが急増する傾向が見られた. 軸ひずみが最大となったのは砕石 5-2.5 mm の単層のケ 一スであり，最小は砕石 40-20 mm の単層のケースであ った. またその他の二層構造のフィルター層については, 両者の中間的な軸ひずみに留まった。このことから，主 要な沈下は各フィルター層の内部で発生しており，二層 構造の境界面における材料の入り込みは少ないものと考 えられる。

次に，移動荷重を想定した鉛直載荷試験における軸ひ ずみを図-7 に示す．水平試験の場合と同様に，応力振幅 の増加に伴って軸ひずみが増加した。前述の水平載荷試

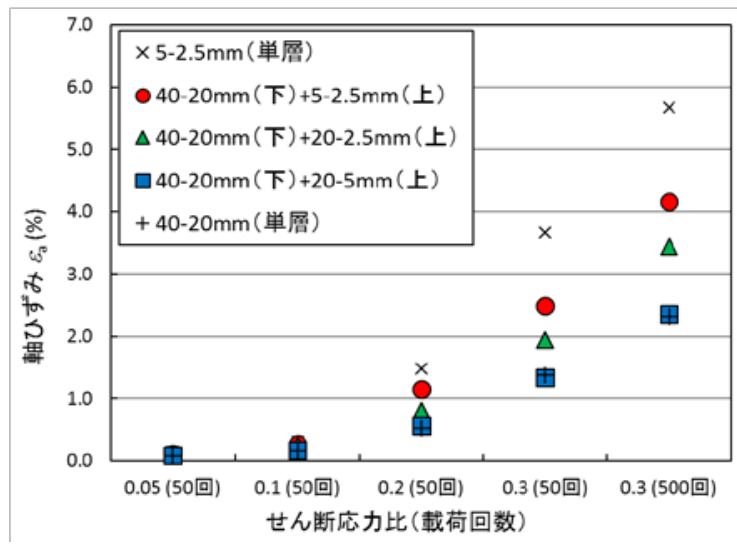

図-6 繰り返し水平載荷試験における軸ひずみ

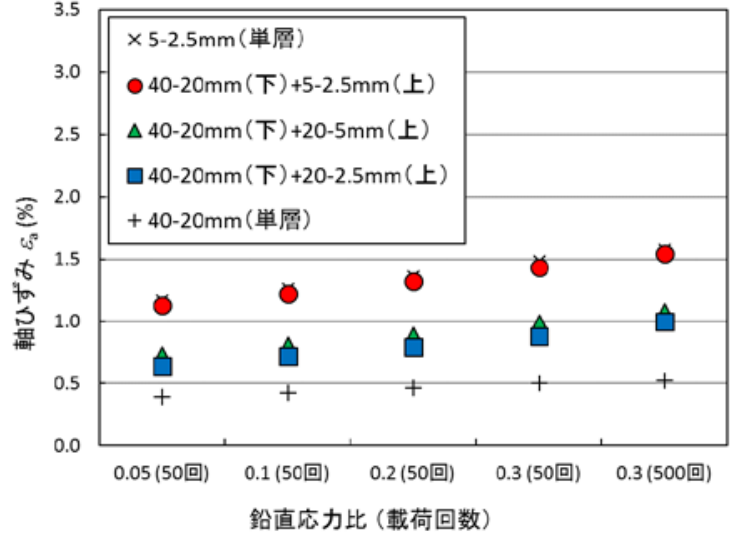

図-7 繰り返し鉛直載荷試験における軸ひずみ 
験と比較すると，試験初期よりある程度（約 0.4-1.2％) の軸ひずみが発生しており，その後の軸ひずみの増加は 穏やかであった．また水平載荷試験と同様に，二層構造 のフィルター層の結果が砕石 5-2.5 mm (単層) と砕石 40-20 mm (単層) の中間的なものに留まった.

以上より，二層構造の境界が弱面となるような現象は 特に観察されず，想定される外力に対して十分な力学的 安定性を有することが明らかとなった。

\section{4. 模型実験による吸い出し・空洞形成・陥没 過程の観察}

\section{(1) 実験概要}

図-8 に示寸模型土槽を用い, 高さ $100 \mathrm{~cm}$, 幅 $400 \mathrm{~cm}$, 奥行き $30 \mathrm{~cm}$ の砂地盤を作成して, 吸い出し・空洞形成・ 陷没の一連の過程を観察した. 図-9に実験の仕様とセン サ一の配置図を示寸，模型砂地盤は水中落下法で作成し た。水位を所定の位置（地盤下端より $20 \mathrm{~cm}$ 上方）に調 整した後，地盤内に配置されたサクション（負圧）計の 值が一定になったことを確認した後に実験を開始した.

表-5に実験ケースの一覧を示す．ケース 1 と 2 では粒形 の異なる海砂 $\mathrm{A}\left(D_{50}=0.242 \mathrm{~mm}\right)$ と海砂 $\mathrm{B}\left(D_{50}=0.585\right.$

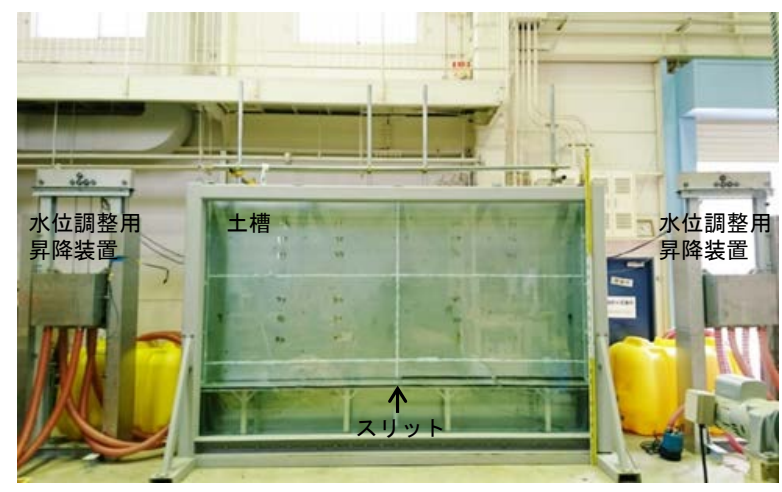

図-8 吸い出し模型土槽の全景

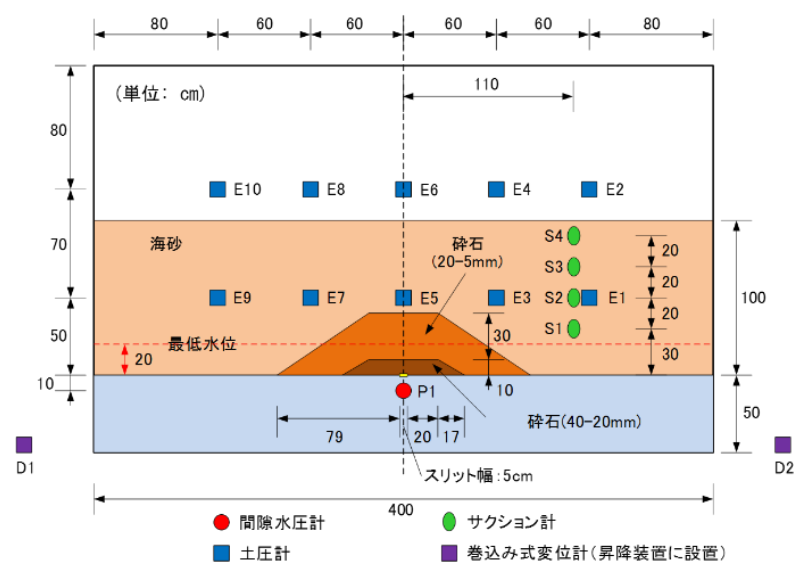

図-9 吸い出し模型試験の仕様とセンサ一配置図

（地盤中央のフィルター層はケース 3 のみ） $\mathrm{mm})$ を用いた. 地盤下端中央に位置する幅 $5 \mathrm{~cm}$ のスリッ 卜を開放することで吸い出しを誘発した，その状態で吸 い出しが一旦終息した後，地下水位面を徐々に上昇させ て更なる吸い出しを促し，最終的に地表面が陮没するま でこれを続けた．ケース 3 では，2 種類の粒度調整砕石 (40-20 mm, 20-5 mm)から成るフィルター層をスリット周 辺に設け, 吸い出し抑止効果を検証した. 実験中は土圧, 間隙水圧，サクションを測定した他，地盤側面からの撮 影画像を元に，DIC (Digital Image Correlation)による解析 4)で地盤変状を定量的に評価した。

\section{(2) 実験結果}

はじめに，各ケースの実験開始直前に計測した地盤内 のサクションの分布を図-10 に示寸．なお，この時点に おける地盤内の水位は地盤下端より $20 \mathrm{~cm}$ 上方にあり, 上部の地盤は地表に近づくほど不飽和な状態となってい る. ケース 1 とケース 2,3 を比較すると，用いた海砂の 粒径に起因してサクションの大きさが異なり，高さ方向 の分布に明確な差が生じた。

次に，各実験ケースにおける土槽側面からの撮影画像 を図-11〜図-13に示す。粒径が細かくサクションの強い 海砂 A を用いたケース 1 では, スリット開放後に地下水 面以下で連続的に吸い出しが発生し，安息角の斜面を形

表-5 吸い出し模型実験のケース一覧

\begin{tabular}{|c|c|c|c|}
\hline \multirow{2}{*}{$\begin{array}{l}\text { 実験 } \\
\text { ケース }\end{array}$} & \multirow{2}{*}{ 模型地盤 } & \multicolumn{2}{|c|}{ 実験ステップ } \\
\hline & & 1 & 2 \\
\hline 1 & $\begin{array}{c}\text { 海砂 } \mathrm{A} \\
\left(\mathrm{D}_{50}=0.242 \mathrm{~mm}\right)\end{array}$ & スリット開放 & $\begin{array}{l}\text { 水位上昇 } \\
(5 \mathrm{~cm} / \mathrm{min})\end{array}$ \\
\hline 2 & $\begin{array}{c}\text { 海砂 } \mathrm{B} \\
\left(\mathrm{D}_{50}=0.585 \mathrm{~mm}\right)\end{array}$ & スリット開放 & $\begin{array}{l}\text { 水位上昇 } \\
(5 \mathrm{~cm} / \mathrm{min})\end{array}$ \\
\hline 3 & $\begin{array}{c}\text { 海砂B } \\
\text { フィルー層 }\end{array}$ & スリット開放 & $\begin{array}{c}\text { 水位上昇 } \\
\& \text { } \\
(50 \mathrm{~cm} / \mathrm{min})\end{array}$ \\
\hline
\end{tabular}

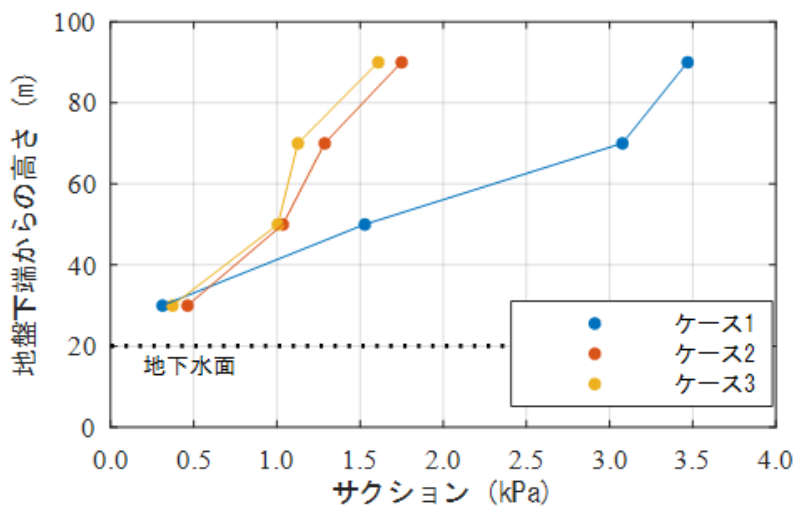

図-10 地下水面上のサクションの分布 
成するまで続いた（図-11(a)）。一方，地下水位以上では 下部地盤の消失に伴って断続的に土塊が崩落し，ドーム 型の空洞を形成した. この時点における空洞周辺の地盤 変状を画像解析 4)によって評価した結果, 空洞へ向かう 方向に最大で $0.8 \mathrm{~mm}$ の変状が認められた. その後、地 下水位を $5 \mathrm{~cm} / \mathrm{min}$ の速さで上昇させると, 砂粒子間のサ クションの消失によって空洞のフロントが進展した（図 -11(b)). 最終的に地下水位が地表面より約 $30 \mathrm{~cm}$ に到達 した時点で陷没が発生した（図-11(c)）。

一方, 粒径が粗くサクションの弱い海砂 B を用いたケ
一ス 2 では，スリット開放後に上に凸な形状の空洞が形 成された（図-12(a)）。この時点において，空洞上部の地 盤が最大 $5 \mathrm{~mm}$ 程度沈下寸る様子が画像解析により確認 された，その後，地下水位を上昇させて間もなく地表面 の陥没に至った（図-12(c)）.

また海砂 B にフィルター層を設けたケース 3 では，ス リット解放後に装置の最速の水位変動 $(50 \mathrm{~cm} / \mathrm{min})$ を複数 回与えても吸い出しは確認できず，フィルター層による 吸い出し抑止効果が実証された（図-15(a)-(c)).

最後に，ケース 1 と 2 における，スリット開放後より

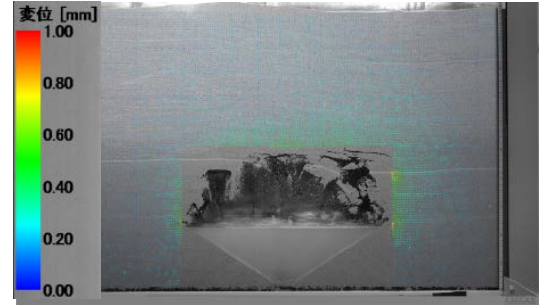

(a) 空洞形成時の地盤変状の可視化

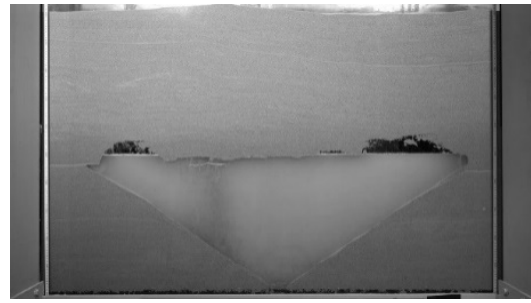

(b) 地下水位上昇による空洞の進展

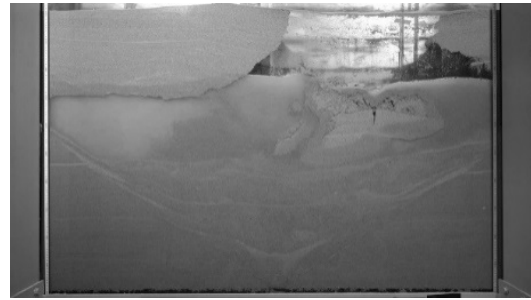

(c) 地表面の陷没

図-11 吸い出し, 空洞形成, 陥没の様子（ケース 1 : 海砂 A）

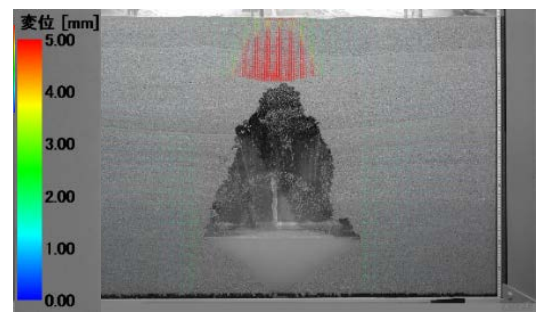

(a) 空洞形成時の地盤変状の可視化
水位上昇開始後間もなく地表面の陥没に至った ため，写真なし

(b) 地下水位上昇による空洞の進展

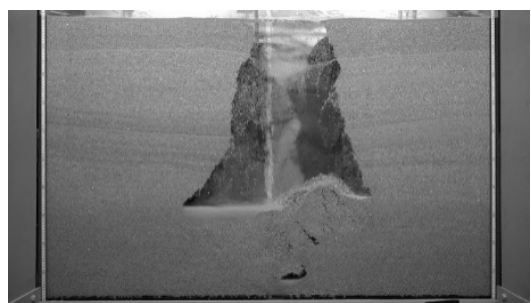

(c) 地表面の陮没

図-12 吸い出し, 空洞形成, 陷没の様子（ケース 2 : 海砂 B)

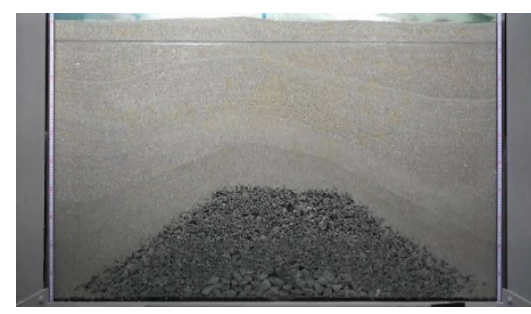

(a) 試験開始直後

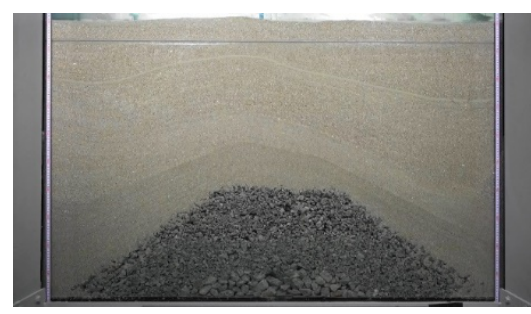

(b) 地下水位上昇 $\&$ 下降の 1 回後

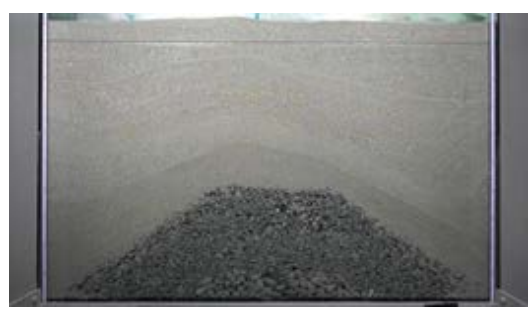

(c) 地下水位上昇\&下降の 5 回後

図-13 水位上昇・下降の繰り返しの様子（ケース 3 : 海砂 B，バリア層あり）

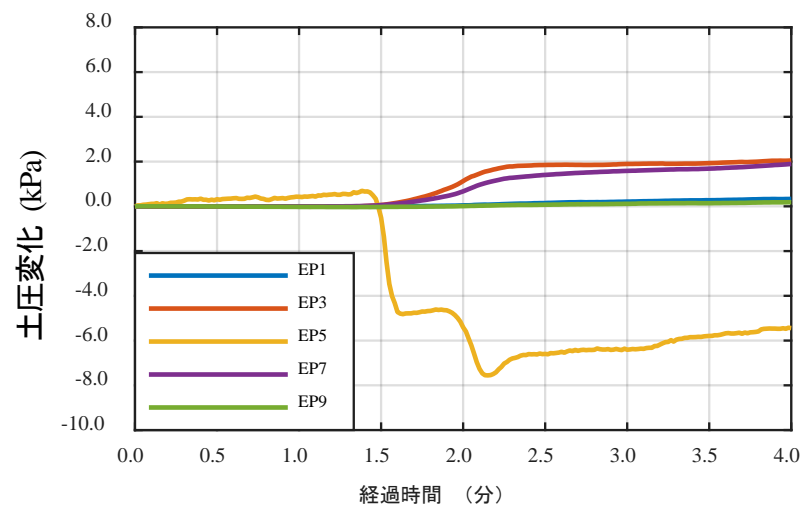

(a) ケース 1 : 海砂 $\mathrm{A}$

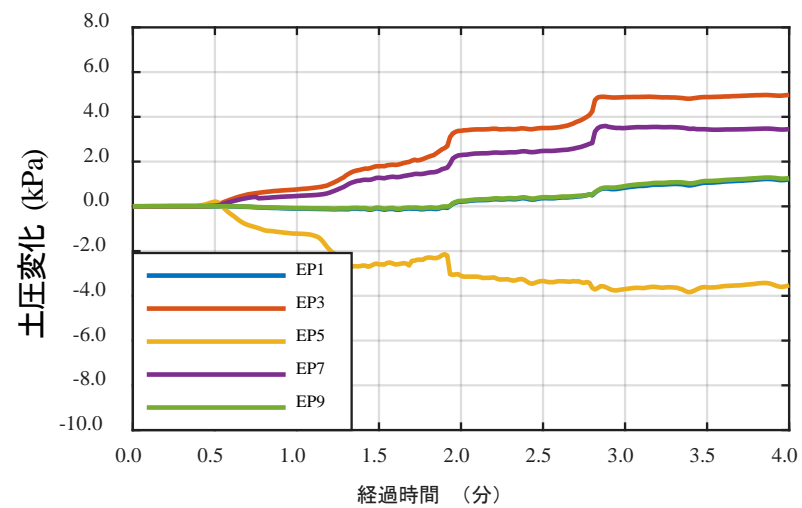

(b) ケース 2 : 海砂 $\mathrm{B}$

図-14 スリット解放から空洞形成時における周辺地盤の土圧変化 
空洞形成に至る段階の土圧変化の時刻歴を図-14 に示す. ケース 1 とケース 2 に共通して, 地盤中央 (EP5) では, 土塊の崩落・消失に伴って土圧が減少した。この際，ケ 一ス 1 と 2 を比較すると，前者は後者よりもよりも土圧 の減少量が大きいことがわかる，これは，粒径が細かく サクションが強いケース 1 では, 粒径が相対的に粗くサ クションの弱いケース 2 に比べて, 崩落する土塊のサイ ズが大きく土圧低下が著しいためである，一方，サクシ ヨンが小さいケース 2 では小さな土塊の崩落がなだらか に続き，土圧の減少も緩やかであった。 また，地盤中央 （空洞の中央軸に対応）から $60 \mathrm{~cm}$ 側方に位置する周辺 地盤 (EP3, EP7)では, 空洞形成に伴って土圧の増加が認 められた. これはアーチ構造によって空洞上部の地盤を 支えることにより，空洞周辺部に応力が集中したものと 考えられる. 特に，ケース 1 に比べてより切り立った空 洞が形成されたケース 2 では，地盤中心から $60 \mathrm{~cm}$ 側方 の EP3 と EP7 で大幅な土圧の増加が確認された。

地盤中央（空洞中央軸）から $120 \mathrm{~cm}$ 側方に離れた場 所 $(E P 1, E P 9)$ においては, 土圧の変化はほぼないが, サ クションが相対的に弱く空洞のフロントが地表に向けて より近づいた時点（ケース 2）において，僅かな応力増 加が確認された.

上記の結果とその比較から，形成される空洞の大きさ や形状には，地盤内のサクションが強く影響することが 分かった. この実験事実は, 護岸背後の吸い出しに伴う 空洞形成及び崩壊場所におけるサクション動態に関する 既往の現地観測事実 5)とも整合的である. 従って，以上 のことは，護岸・岸壁などの港湾施設の維持管理におい て重要な知見といえる。
本研究では，護岸・岸壁の吸い出し抑止対策として, 二層構造のフィルター層の実用性に関する総合的な検討 を行った. 単粒度のフィルター層を対象とした目詰まり 効果の検証により，国際基準に定められる従来のフィル タ一材と比較して，同等かそれ以上の効果を持つことを 示した．地震荷重，交通荷重を想定した繰り返し載荷試 験からは，二層の粒度調整砕石から成るフィルター層が 十分な力学的安定性を有することが明らかとなった。裏 埋砂を用いた模型実験により，実現象に近いスケールで 吸い出し，空洞形成，地表面陥没の一連の過程を可視化 すると共に，裏埋砂の粒径に起因するサクションの大き さが，これらのプロセスに多大な影響を及ぼすことを示 し，フィルター層の吸い出し防止効果を実証した.

\section{参考文献}

1) 小林孝彰, 佐々真志，鈴木高二朗，渡辺啓太，具志良太， 前里尚, 平野年洋 : フィルター層による吸い出し防止と防 砂シートの損傷リスク低減効果に関する検討，土木学会論 文集 B3（海洋開発），73(2),pp.354-359, 2017

2）伊藤克彦，大北康治，松澤宏 : 砕石ドレーンにおける 目詰まり防止に関する研究, 土木学会論文集, No.439, III-17， pp.53-62， 1991

3) U.S. Bureau of Reclamation: Design of Small Dams, 1998

4) Takano, D., Lenoir, N., Otani, J., Hall, S.A.: Localised deformation in a wide-grained sand under triaxial compression revealed by X-ray tomography and digital image correlation, Soils and Foundations, 55(4), pp.906-915, 2015.

5) Sassa, S., Li, F. and Sekiguchi, H.: Response of saturated/unsaturated gravelly sand to tidal fluctuations, ASCE Geotechnical Special Publications No. 143, pp. 174-186, 2005.

(2018.2.8 受付)

\title{
5. 結論
}

\section{VISUALISATION OF THE INTERNAL EROSION AND CAVITY FORMATION OF RECLAIMED SAND AND ITS PREVENTION BY GEOTECHNICAL FILTER}

\author{
Takaaki KOBAYASHI, Shinji SASSA, Soonbo YANG and Shoya GOTO
}

The practicality of two-layered geotechnical filter for erosion protection in coastal facilities was investigated. Fist, the performance of geotechnical filters with a narrow grain size distribution was experimentally investigated and verified in view of the existing standard. Secondly, the mechanical stability of two-layered geotechnical filter was examined against earthquakes and traffic loads. Thirdly, the process of the internal erosion, cavity formation and collapse of reclaimed sand was observed by physical modelling tests and the effectiveness of the proposed geotechnical filter as the preventive measures was confirmed. 